UOT 544.653

\title{
RESEARCH INTO ECOLOGICAL CONDITIONS OF KAKHETI REGION PASTURES IN GEORGIA ON THE BASIS OF ANIMAL HAIR ANALYSIS
}

\author{
T.R.Chelidze*, L.G.Enukidze*, M.V.Chankashvili*, T.Zh.Loladze*, B.U.Imnadze** \\ *R.Agladze Institute of Inorganic Chemistry and Electrochemistry, \\ Iv.Javakhishvili Tbilisi State University 11 \\ Mindeli str.,0186,Tbilisi,Georgia;e-mail: tamchelidze@yahoo.com \\ **Agrarian University of Georgia \\ 13 km, David Aghmashenebeli alley,0131, Tbilisi, Georgia; e-mail: bimna2012@agruni.edu.ge
}

\begin{abstract}
Contamination of environment with heavy metals is mainly caused by emissions of anthropogenic origin. The paper deals with the definition of heavy metals (copper, lead, zinc and cadmium) in the hair of cows and sheep from a Georgia 's region. Samples of animal hair were collected from 20 sheep and 10 cows in the municipalities of Kakheti - Gurjaani, Akhmeta and Sagarejo.The investigation was carried out by differential-impulse polarography method. It revealed that toxic metal content in the hair of animals of this region is in line with international standards which reaffirms the ecological purity of the said pastures.
\end{abstract}

Keywords: animal hair, heavy metals, environment, polarographic method.

\section{Introduction}

Pollution of the environment is the violation of ecosystem that causes instability, disorder, harm or discomfort in physical systems or living organisms. High concentration of pollutants in the atmosphere and lithosphere is usually discovered in areas close to the pollution, but sometimes they move 100 and $1000 \mathrm{~km}$ away under the influence of wind and water to affect the biosphere and the world's nature as a whole [1]. There are several ways for microelements to invade into living organism. The major way is an ecologically polluted soil where cultivated plant and/or corns are used as food. At present, the study of the animal hair is considered to be a question of great interest from standpoint of identification of soil pollution by toxic elements. These animals inhabit the one and same living space with men and eat grass on pastures. Therefore, biomonitoring of chemical pollutants becomes increasingly important in various countries $[2,3]$. That allows discussing simultaneously the concentration of toxic compounds in living organisms and ecological quality of the pastures. It should be noted that collection of samples through cutting hair is absolutely harmless for animals, does not injure them and thus reduces the risk of possible pollution. A question of animal hair is poorly explored, especially in Georgia. Last year, we examined two various regions of Georgia - Tetritskaro and Khoni municipalities [4,5]. Now, we are engaged in exploring Khaxeti region municipalities of Gurjaani, Akhmeta and Sagarejo which are located in the south-eastern part of Georgia at the height of 460 (1200) 1800 (2000) above sea level. This region is characterized by humid climate, cold winters and cool summers. The analysis of toxic metals should be performed to comply with international standards and in accordance with the Hazard Analysis and Critical Control Points (HACCP of the FAO/WHO) and Commission Regulation (EC) [6].

Ingestion of excessive mineral doses by animals takes place differently, for instance, a mistake in balancing mineral supplements and/or complete feed, intake of plants or use of fertilizers, herbicides and fungicides on pastures. Moreover, decomposition of municipal waste, leaks and accidental spills of pollutants may lead to the accumulation of toxic minerals in the environment. 


\section{Objectives and Methods}

Investigation will be performed through differential-impulse polarographic methods with a dropping mercury electrode $(\mathrm{t}=3.5 \mathrm{sec}, \mathrm{m}=2.6 \mathrm{mg} / \mathrm{sec})$ by a three electrode cell. The value of potential was taken towards to the saturated calomel electrode potential. Selection, preparation and processing of wool sample were carried out by a method we suggested [7]. Analytical procedure included: a careful washing technique, drying at $100^{\circ} \mathrm{C}$ for an hour, weighing and burning at $450^{\circ} \mathrm{C}$ for 5 hours in a quartz vessel. Obtained ash was treated by $1 \mathrm{~N} \mathrm{HNO}_{3}$ and evaporated. After this, $1 \mathrm{~N} \mathrm{HCl}$ was added and evaporated again. An ash obtained as a result of hair mineralization was dissolved in $10 \mathrm{ml}$ of $0.1 \mathrm{~N}$ $\mathrm{HCl}$ and recorded through polarographic curves.

\section{Results and Discussion}

The results of polarographic analysis of heavy metals content in the scalp hair of sheep are represented in Fig.1 which shown that of three investigated microelements $(\mathrm{Cu}, \mathrm{Pb}$ and $\mathrm{Zn}$ ) gives a sharp peaks at a certain very specific value of potential in accordance each of them. As for cadmium, it has not been discovered in sheep wool and that of cow alike. Table 1 shows that explored elements does not exceed the world international standards conformably to the ecological purity of the region. Probably, in this case, plays a significant role both mountain location of pastures and the character of soil. The high value $\mathrm{pH}$ of soil this region is reason of low concentration of cadmium.

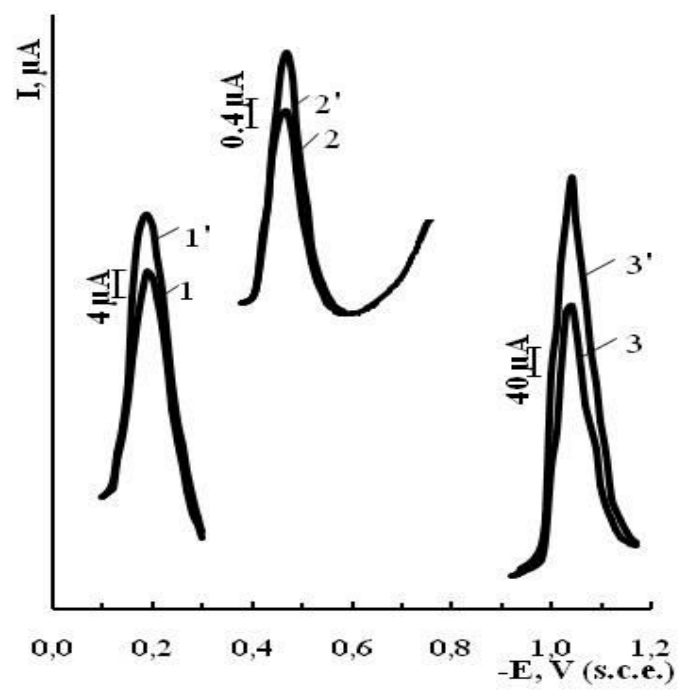

Fig. 1. Polarograms for heavy metals in $1 \mathrm{~g}$ sample of the sheep and cow hair in the supporting electrolyte of $0.1 \mathrm{M} \mathrm{HCl}: 1$ - Cu (II), 2 - Pb (II), 3 - Zn (II); 1',2',3' - appropriate standard solutions.

Table 1. Results of research into the content of $\mathrm{Cu}, \mathrm{Pb}, \mathrm{Cd}$ and $\mathrm{Zn}$ ions in the hair of cow and sheep in Kakheti region

\begin{tabular}{|c|c|c|c|c|}
\hline & $\mathrm{Cu}, \mathrm{mg} / \mathrm{kg}$ & $\mathrm{Pb}, \mathrm{mg} / \mathrm{kg}$ & $\mathrm{Cd}, \mathrm{mg} / \mathrm{kg}$ & $\mathrm{Zn}, \mathrm{mg} / \mathrm{kg}$ \\
\hline Cow & $5.00 \div 5.44$ & $0.49 \div 0.79$ & 0.00 & $89.58 \div 297.43$ \\
\hline Sheep & $0.97 \div 4.94$ & $0.00 \div 0.67$ & $0.00 \div 0.03$ & $70.08 \div 107.13$ \\
\hline
\end{tabular}




\title{
Conclusion
}

On the basis of our investigation it has been established that none of toxic metal content in the hair of 10 cows and 20 sheep scalp from the said region exceeds limits as set forth in International standards, consequently, in the region where there is no need in any operations for cleaning soil.

\section{REFERENCES}

1. Chojnacka K., Saeid A., Michalak I., Mikulewicz M. Effects of local industry on heavy metals in human hair. Environ. Toxicol. Pharmacl. 2012, vol. 34,pp. 1563-1570.

2. Pourjafar M., Badiei, K. Cattle hair as a biomarker of lead pollution in the region of the Shiraz oil and petrochemical industries in Iran. International Journal of Veterinary Research. 2010, vol.4, no. 3, pp. 141-145.

3. Kozak M., Kralova E., Sviatko P. and others. Study of the content of heavy metals related to environmental load in urban areas in Slovakia. Bratisl Lek Listy. 2002, pp. 103-111. 4. Chelidze T.R., Enukidze L.G., Chankashvili M.V., Loladze T.Zh. Content of Heavy Metals in Animal Hair and its Relation with Ecological State of the Pastures in Tetritskaro
Municipality of Georgia. Annals of Agrarian Science. 2015, vol. 13, no. 2, pp. 67-72.

5.T.Chelidze T., Enukidze E., Chankashvili M., Loladze T. Animal Hair as Biological Indicator for Heavy Metal Pollution in the Two Regions of Georgia. Proceedings of the International conference Advanced Materials and Technologies (ICAMT), Tbilisi, 2015, pp. 283-285.

6. Official Journal of the European Union, Commission Regulation (EC), 2006, no. 1881.

7. Enukidze L., Chelidze T., Shavgulidze N. and others. Elaboration of a New Method of Determination of some Heavy Metals in Vegetable Materials by Differential-pulse Pholarography. Georgian Engineering News. 2009, vol. 49, no. 1, pp. 158-160 (in Russian).

\section{ИССЛЕДОВАНИЕ ЭКОЛОГИЧЕСКОГО СОСТОЯНИЯ ПАСТБИЩ ОДНОГО ИЗ РЕГИОНОВ ГРУЗИИ - КАХЕТИИ НА ОСНОВЕ АНАЛИЗА ШЕРСТИ ЖИВОТНЫХ}

\author{
Т.Р.Челидзе*, Л.Г.Енукидзе*, М.В.Чанкашвили*, Т.Ж.Лоладзе*, Б.У.Имнадзе \\ *Институт неорганической химии и электрохимии им. Р.Агладзе, \\ Тбилиский Государственный Университет \\ Грузия 0186, Тбилиси, ул.Миндели,11; e-mail: tamchelidze@yahoo.com \\ **Аграрный Университет Грузии \\ Грузия 0131, Тбилиси, алея Давида Агмашенебели, 13 км; e-mail: bimna2012@agruni.edu.ge
}

\begin{abstract}
Загрязнение окружающей среды тяжелыми металлами, в основном вызвано эмиссией антропогенной природой. Работа посвящена определению тяжельх металлов (медь, свинеи, иинк и кадмий) в шерсти животных - коров и овеи одного из регионов Грузии. Образиы животной шерсти были собраны в следуюших мунищипалитетах Кахетии: Ахмета, Гурджаани и Сагареджо от 20 овеи и 10 коров. Исследования проводились методом дифференциальноимпульсной полярографии. Было установлено, что содержание исследуемых токсичных элементов в шерсти животных этого региона соответствует нормам международных стандартов, что указывает на экологическую чистоту указанных пастбищ.
\end{abstract}

Ключевые слова: шерсть животных, тяжелье металль, окружающая среда, полярографический метод.

Поступила в редакиฺию 29.11.2016. 